\title{
Understanding Urban Chinese Primary School Pupils' Language Learning Strategies For Listening and Speaking
}

Pang Wan Ji, Farouk Rupiwin, Chua Pei Chia, Koet Tian Wei, Noor lylia Abu Bakar, Harwati Hashim

To Link this Article: http://dx.doi.org/10.6007/IJARBSS/v11-i6/10196

DOI:10.6007/IJARBSS/v11-i6/10196

Received: 10 April 2021, Revised: 12 May 2021, Accepted: 28 May 2021

Published Online: 14 June 2021

In-Text Citation: (Pang et al., 2021)

To Cite this Article: Pang, W. J., Rupiwin, F., Chua, P. C., Koet, T. W., Abu Bakar, N. I., \& Hashim, H. (2021). Understanding Urban Chinese Primary School Pupils' Language Learning Strategies For Listening And Speaking. International Journal of Academic Research in Business and Social Sciences, 11(6), 613-633.

\section{Copyright: @ 2021 The Author(s)}

Published by Human Resource Management Academic Research Society (www.hrmars.com)

This article is published under the Creative Commons Attribution (CC BY 4.0) license. Anyone may reproduce, distribute, translate and create derivative works of this article (for both commercial and non-commercial purposes), subject to full attribution to the original publication and authors. The full terms of this license may be seen at: http://creativecommons.org/licences/by/4.0/legalcode

\section{Vol. 11, No. 6, 2021, Pg. 613- 633}

Full Terms \& Conditions of access and use can be found at http://hrmars.com/index.php/pages/detail/publication-ethics 


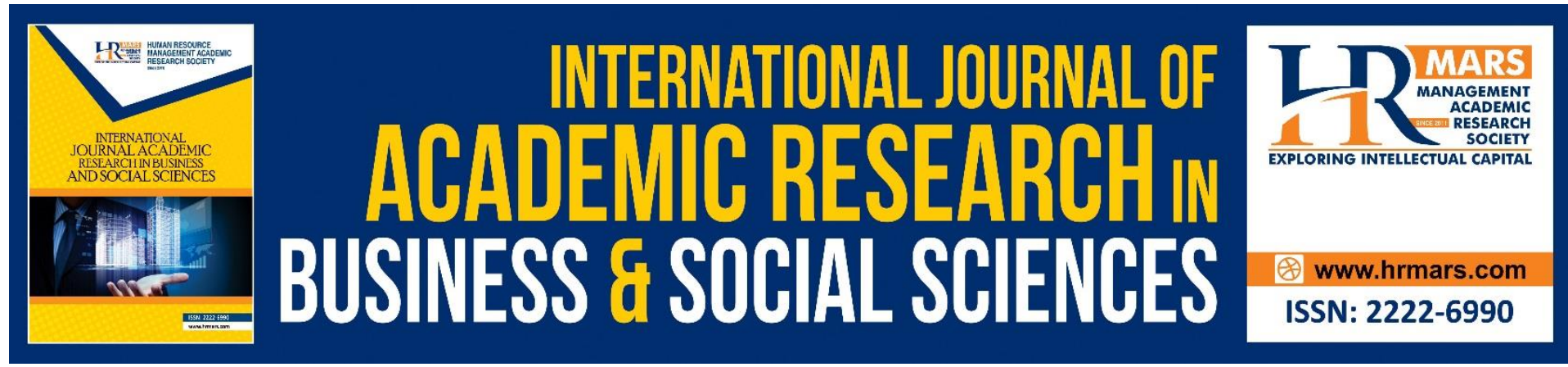

\title{
Understanding Urban Chinese Primary School Pupils' Language Learning Strategies For Listening and Speaking
}

\author{
Pang Wan Ji, Farouk Rupiwin, Chua Pei Chia, Koet Tian Wei, \\ Noor Iylia Abu Bakar, Harwati Hashim \\ Faculty of Education, Universiti Kebangsaan Malaysia, Selangor, MALAYSIA. \\ Email:wanji1501@gmail.com, farouk.rupiwin@gmail.com, peichia11@gmail.com, \\ twkoet.10415@gmail.com, ii9354@gmail.com, harwati@ukm.edu.my
}

\begin{abstract}
Many studies have shown the effectiveness of language learning strategies by second language learners. However, only a few studies explored language learning strategies used by primary school pupils, especially in improving their listening and speaking skills. This study aims to identify language learning strategies used by Year 6 ESL learners to improve their listening and speaking skills. This study employed a quantitative method. A total of 40 pupils from Year 6 pupils in an urban Chinese Type Primary School in Penang, Malaysia were selected using a convenience sampling technique. The questionnaires were adapted from the Young Learners' Language Strategy Use Survey (Cohen and Oxford, 2002), focusing on listening and speaking skills. The findings show that the respondents use language learning strategies in learning English specifically for listening and speaking skills. Although different learners used different language strategies, there are some strategies that are used by most of them. This shows that the learners adopt some language learning strategies in learning English without being aware of it. Thus, teachers should play a role in guiding them to make use of these strategies effectively in acquiring the English language.
\end{abstract}

Keywords: Language Learning Strategies (LLS), English as a Second Language (ESL), Listening Strategy, Speaking Strategy, Young Learners

\section{Introduction}

The learning trend in the $21^{\text {st }}$ century is no longer focussing on gaining knowledge to score in examinations. It is a lifelong process to acquire knowledge, skills and competencies in order to develop future opportunities. Gilbert (2005) stated that knowledge is not only about storing ideas for recall purpose but more to application of the understanding. It can be seen that acquiring knowledge and making use of the knowledge in daily life is the ultimate goal of learning. However, the acquisition of knowledge in the learning process does not only depend on the teaching methods used by teachers to help learners excel in examinations but also the responsibility of the learners in their own learning. Learners should be active throughout the learning process and apply what they have learnt instead of waiting for teachers to spoonfeed them with information. This statement is in line with Wolff, Wagner \& Poznanskiet et al. 
(2015) who pointed out that active learning can lead to better knowledge retention and deeper understanding of materials than passive learning. Thus, it is important that teachers can increase the potential of learners in taking charge of their own learning and dealing with the learning challenges. In realising this effort, learners shall be motivated to use different learning strategies in the learning process.

Learning strategies are defined as "specific actions taken by the learner to make learning easier, faster, more enjoyable, more self-directed, more transferable to new situations" (Oxford, 1990, pp.8). Learning strategies are also techniques used to aid a learning task (Chamot, 2005). In other words, learners use a set of techniques or skills to help them learn better, faster and more efficiently. Learning strategies might be unfamiliar to learners to be applied in their learning task at first, but with repeated usage of the strategies, learners will slowly become familiar and apply the strategies with some automaticity. To date, researchers are interested in exploring the process of learning rather than the product of learning. Previous studies have proven that learners who apply effective learning strategies were more likely to have better learning experiences and positive attitudes toward language learning (Habók \& Magyar, 2018). Therefore, successful learners who apply suitable learning strategies are more aware of their learning process and will be more responsible and efficient in completing their learning task.

For many years, language has been regarded as a means of communication among people regardless of their different races and colours. Language is extremely necessary in our lives because it is the means by which individuals communicate. However, learning a language can be quite challenging. Oxford (1990) strongly emphasised the vital role of language learning strategies (LLSs) in language learning. In her studies, it is found that successful language learners applied more strategies that suit their learning styles than the less successful learners. There are also other studies which support language learning strategies as one of the factors that affect language proficiency (Green \& Oxford, 1995; Gharbavi \& Mousavi, 2012; Raoofi, Binandeh \& Rahmani, 2017). By identifying the language learning strategies used by the successful learners, less successful learners can be trained with suitable language learning strategies so that they can apply these strategies to aid their learning.

In today's world, English is considered the most commonly used language in the world as it helps to connect everyone in a global world. Therefore, it is important that students can master the language and communicate effectively in English. In the Malaysian context, English is taught as the second language in all Malaysian schools. It is also a compulsory subject to be learnt by all the students in both primary and secondary schools. It is hoped that students will be equipped with basic English language skills in schools to enable them to communicate in a variety of contexts. There are four language skills, namely listening, speaking, reading and writing skills that should be mastered by ESL pupils so that they can understand the information in both spoken or written in their everyday life.

According to Ulum (2015), listening skill plays an important role in language learning as it promotes the learning of other language skills by the language input received. However, it is also the hardest skill to learn. Speaking skill, on the other hand, is vital to convey meaning in conversations. Without speaking ability, one cannot communicate well and might impede his or her social development. Therefore, it is crucial to build up students' communicative 
competence during the learning of English. Though communicative competence is listed as one of the $21^{\text {st }}$ century skills to be mastered by students, listening and speaking skills are given less focus as compared to reading and writing skills (Sah \& Shah, 2020). The same finding was mentioned by Nunan (1997) that listening skill had not been given much focus as compared to reading skill. This is due to the more emphasis given to the centralised public summative examinations, which focus more on the reading and writing skills. Instead of exploring and acquiring knowledge for the sake of self-improvement, students pay more attention to reading and writing skills and neglect the listening and speaking skills. This leads to the lack of knowledge in using suitable listening and speaking learning strategies during their language learning process.

Many researchers agree that language learners can be trained with language strategies so that they can be successful language learners (Gharbavi \& Mousavi, 2012; Suwanarak, 2019). However, limited studies were done to identify the students' listening and speaking strategies specifically in their learning process in order to improve the mastery of these two skills in the English language. By identifying the students' listening and speaking learning strategies, this research will be useful to give insight to the school administrators and English language teachers into the language learning strategies that are suitable for students to improve their English language communicative competence interventions. It also helps English language teachers to identify their roles and the right teaching approaches to teach these strategies to the students.

\section{Research Objective}

- To identify language learning strategies used by Year 6 ESL learners to improve their listening and speaking skills in an urban primary school located in Penang, Malaysia.

\section{Research Questions}

1. To what extent do the Primary 6 ESL learners use listening strategies in their language learning process?

2. To what extent do the Primary 6 ESL learners use speaking strategies in their language learning process?

\section{Literature Review \\ Overview of Language Learning Strategies}

Language learning strategies, according to Oxford (1989), are the conscious process of behaviours used by language learners to improve language acquisition, storage, retention, recall, and adoption of new information. Language learning strategies, according to Cohen (1998), are the mechanisms that learners actively choose and that can produce outcomes to enhance the learning or application of a second language through the storage, retention, recall, and adoption of language information. Cohen (1995) characterised "strategies" in the context of second language acquisition as "universal approaches and definite acts or means applied to acquire a second language."

Language learning techniques, according to Wenden (1991) and Rubin (1994), are the designs, behaviours, and practices used by the learner to access, store, retrieve, and apply information. They argue that the aim of using LLSs is to remember language information, recall it, and apply it in a different situation. In that case, they clarify that LLSs refer to what students do to learn and change their learning. LLSs are later proposed by Richards and Platt 
(1992) as a voluntary action that allows learners to comprehend, gain, and remember new knowledge. LLSs are used for a variety of purposes. The difference between Wenden and Rubin's description and Richards and Platt's can be explained by the fact that Richards and Platt's LLSs are used consciously, which means that learners know what works best for them based on the learning objective.

According to LLSs, Macaro (2014) identified that certain techniques needed a basic level of linguistic awareness to be used. LLSs may also be thought of as mental exercises that students or language learners engage in to learn a foreign language. Furthermore, LLSs serve as a forum for language learners to improve their comprehension as they progress toward language proficiency (Oxford \& Nyikos, 1989). Language learners will be able to completely comprehend new details about the new language they are learning through mental exercises before assimilating it into their current experience. Learning strategies are mental strategies through which learners associate new knowledge with existing information in long-term memory, according to Oxford and Nyikos (1989). Language learning strategies can then be described as deliberate, deliberate steps taken to resolve certain educational obstacles, depending on the issue at hand. They are used to remember details, to integrate them, and to apply them in speaking and writing.

Ellis (1994) concluded five dominant conditions of effective or strong language learners, which include an interest in language form, a topic for discussion, an active task strategy, awareness of the learning cycle, and the ability to implement techniques easily matched with task specifications, based on a previous study on successful language learners. Wenden (1991) identified two main learning strategies: cognitive strategies (information selection, comprehension, storage, and retrieval) and self-management strategies (monitor or manage learning processes such as regulatory skills or self-directed learning skills). The Education Plan Cohen and Chi developed the Use Inventory, which is a common language learning technique inventory (2004). To assess strategy use, it has parts for listening, speaking, vocabulary, writing, reading, and translation.

\section{Listening and Speaking Strategies}

Listening is an active skill as it requires learners to really pay attention to what they are listening to in order to gain understanding. In LLSs, listening strategies refer to specific methods or techniques language learners use to learn a new language through listening. Listening is a vital part of all learning (Chitravelu, Sithamparam \& Choon, 2005), and it is a challenging skill to teach (Chitravelu, Sithamparam \& Choon, 2005; Celce-Murcia, Brinton \& Snow, 2014) because a teacher needs to ensure the learners are always motivated to learn (Chitravelu, Sithamparam \& Choon, 2005). Celce-Murcia, Brinton, and Snow (2014) found that learners and teachers had two issues with listening: a lack of awareness of what listening entails and how comprehension is achieved.

As a part of language skills, speaking is the essence of communication because most speaking is one part of a two-way conversation (Shin \& Crandall, 2014). Through speaking, the speakers in the context of this study language learners can communicate or convey information to others. In addition, they are able to express themselves and their thoughts through speaking. According to Shin and Crandall (2014), a person must be able to talk and think at the same time in order to speak fluently. This is related to why speaking is considered a challenging process that demands both speaking and learning and speaking at the same time. Appropriate speaking strategies are crucial to ensure the productivity of communication or what is intended to say. 


\section{Categorisation of Learning Strategies}

Language learning techniques have been classified by various researchers into various groups. Despite the differences in participants and backgrounds, there are several similarities in the categorisation of learning techniques. Since the publication of books by O'Malley and Chamot (1990) and Oxford (1990), the study of language learning strategy has sparked a lot of interest in the aspect of second language acquisition of which O'Malley and Chamot (1990) and Oxford (1990) categorisation are two of the most well-known (1990). O'Malley and Chamot (1990) identified three types of strategies. Metacognitive strategies like selective attention, preparing, tracking, and assessing learning activities, cognitive strategies like preparation, organisation, inferencing, summarising, minimising, imagery, transition, and elaboration, and social or affective strategies like questioning for clarity, cooperation, and self-talk were among the categories.

According to an overview of previous work on good language learning strategies, Oxford (1990) introduced a more systematic categorisation of language learning strategies, and her categorisation is the most detailed learning strategies categorisation (Ellis, 1994). Language learning techniques were divided into two categories: indirect and primary. In terms of indirect strategies, metacognitive strategies enable learners to monitor the learning process by concentrating, arranging, drafting, and assessing their own mindset. Affective interventions are used to change people's motivations, feelings, and behaviours. Social strategies enable students to learn by working together with others. There are 19 subsets and 62 specific strategies for each of the meta strategies that language learners use to gain a large pattern of vocabulary and language structures. Direct strategies include memory strategies that allow learners to keep and recapture new information, such as organising, creating mental links, applying images and sound, reviewing, and employing action and cognitive strategies that allow learners to comprehend and create a new language, such as reasoning, logical reasoning, and using action (Oxford, 1990). (Oxford, 1990). All of these techniques can be used to alter language learning without impacting the target language directly (Oxford, 1990).

Many different kinds of language learning methods have been classified by researchers (Cohen \& Chi, 2004; Purpura, 1999; Oxford, 1990; O'Malley \& Chamot, 1990; Rubin, 1981; Wong-Fillmore, 1979; Naiman et al., 1978). By evaluating, measuring, and interviewing ineffective and competent learners in a school, Naiman et al. (2018) identified five major learning strategies: active task approach, management of affective demands, self-monitoring, the realisation of language as a mechanism, and realisation of language as a medium of communication. Wong-Fillmore (1979) studied five Mexican students studying English in school and found three social strategies for joining a group or seeking support from a peer, as well as five cognitive strategies for locating a persistent segment in the established formulas used by students to improve their communicative proficiency. Wong-Fillmore also disagreed that social strategies were more important than cognitive strategies in terms of increasing learners' exposure to the second language.

\section{Importance of Language Learning Strategies}

Language learning strategies are important for second language teaching and learning because they promote learning autonomy and competence while also serving as tools for successful, self-directed involvement. Competent LLSs may also assist unsuccessful students in determining the reason for their failure and assisting them in planning their learning (Gregersent, 2001; Chamot, 1999; Brown, 1994; Cohen, 1990; Faerch \& Kasper, 1984). 
Kumaravadivelu, 2003; Griffiths \& Parr, 2001; Murat, 2000; Rubin 1994; Oxford, 1990; Cohen, 1998; Clouston, 1997; O'Malley \& Chamot, 1990). The importance of concentrating on LLSs studies has been shown by research. According to Murat (2000), the primary goal of experimental work in this area is to develop skills that can be used to improve language teaching and learning in second language classrooms. However, rather than being part of prevailing pedagogical guidelines and procedures, trials at integrating technique instruction as the main component of instructed language learning remain at the level of confined intervention.

\section{Methodology}

This study aimed to investigate Year 6 (12-year-old) pupils' language learning strategy used in learning English.

\section{Research Design}

The survey design was used as the research design of this study. The survey questionnaire was developed by adopting the Young Learners' Language Strategy Use Survey by Rebecca Oxford and Cohen (2002). The survey questionnaire was used to collect the data needed to answer the research questions.

\section{Research Participants}

The samples of this study were 40 Year 6 pupils in an urban Chinese Type Primary School in Penang, Malaysia. The respondents had had exposure to English language learning from preschool until Year 6 under the Standard-based English Language Curriculum (KSSR). All respondents have different levels of English language proficiency ranging from average to above average.

\section{Sampling Technique}

Convenience sampling technique was used to conduct this study. A link to the online questionnaire survey was shared in the Google Classroom with the selected class. All pupils in this class were instructed to participate in and complete the survey.

\section{Instruments}

The instrument used in this study is a set of questionnaires adapted from the Young Learners' Language Strategy Use Survey (Cohen \& Oxford, 2002) that incorporates six categories of language learning strategies, namely listening strategies, vocabulary strategies, speaking strategies, reading strategies, writing strategies and translation strategies. In the questionnaire of the study, only the listening and speaking parts are included to address the research questions. It consists of 31 items in statement form and respondents are to choose the score of $100 \%$ if the statement really describes them, $50 \%$ if the statement is somewhat like them and $0 \%$ if the statement is not like them. This adaptation was made as compared to the original survey where the respondents chose among $(+),(v)$ and $(-)$ because the idea was more easily explainable as the pupils had learned the adverbs of frequency.

\section{Data Collection Methods}

The online questionnaire was posted in the Google Classroom and the respondents were given instructions to complete the online questionnaire (Google Form). The respondents' responses were recorded and collected to be analysed. 


\section{Data Analysis}

Data from the questionnaire were analysed using descriptive analysis. Mean, percentages and frequency of responses were obtained. The mean score was used to determine the level of frequency of language learning strategies used by the respondents. The percentages of responses were used to investigate how varied the respondents' employment of the learning strategies. The level of frequency was used to determine the level of usage of the learning strategies when learning English (high, medium, low).

\section{Findings and Discussion}

Table 1 shows the demographic profiles of the respondents. The respondents are Primary 6 pupils and they are currently studying in an urban primary school located in Penang, Malaysia. A majority of the respondents are Chinese and their mother tongue (L1) is Chinese language.

Table 1: Demographic profiles of the respondents

\begin{tabular}{|c|c|c|c|}
\hline \multirow{2}{*}{ No. } & \multicolumn{2}{|c|}{ Item } & $\%$ \\
\hline 1 & Gender & Male & $16(40)$ \\
\cline { 3 - 4 } & & Female & $24(60)$ \\
\hline 2 & Race & Chinese & $40(100)$ \\
\hline 3 & Primary & Six & $40(100)$ \\
\hline
\end{tabular}

\section{Research Question 1}

To what extent do the Primary 6 ESL learners use listening strategies in their language learning process?

The findings in Table 2 are to answer the first research question. Table 2 shows the results on listening strategies used by the respondents. As shown in Table 2 (Section 1), strategy "If I hear people speaking English, I listen" denoted the highest mean score (2.68), and the percentage of respondents $(70.0 \%)$ and $(27.5 \%)$ who thought that this statement really describes them and somewhat like them, respectively. It was presumably due to the pupils' daily routine. It is to be understood based on the respondents' demographic profiles that children of the Chinese descent and those who are studying in an urban school are more likely burdened with tuition for academic purposes or involved in extracurricular activities. Therefore, the respondents have more opportunities to encounter people that speak the target language and less leisure time to spend on electronic gadgets at home. Meanwhile, only one respondent (2.5\%) did not listen to people speaking the language. This implied that 39 respondents (97.5\%) listened to people speaking the language to listen more to the English language. Consequently, Penang is located within Malaysia's metropolitan area, which means most of the adult citizens there have basic English communication skills to interact amongst racially diverse people. The findings in Table 2 also showed that the strategy "I watch TV shows in English" has the lowest mean score (2.10). It was probably a result of the time constraint and pressure from their parents to emphasise their academic achievement. Thus, 
they rarely have time to watch television, and even if they do have the time for it, the shows would be in Chinese because that is their first language.

The findings in Table 2 (Section 2) also disclosed that 36 respondents (90\%) listened to the rise and fall of the sounds, specifically the tones in English, in order to understand sounds and this strategy denoted the highest mean score (2.55). It is also revealed that the strategy "I listen to the rise and fall of the sounds (the music of the language)" indicated the lowest mean score $(1.85)$, but there were 34 respondents $(85 \%)$ that used this strategy to understand sounds in English. The Chinese language is a tonal language (Ortega-Llebaria \& Wu, 2020). Therefore, the respondents are more sensitive to the tones in the language when used verbally. However, the majority of the respondents used all four listening strategies listed in Section 2 based on the mean scores of 1.85 and above.

Next, as shown in Table 2 (Section 3), the strategy "I listen for the important words" indicated the highest mean score (2.70) and the percentage of respondents (27.5\%) and $(72.5 \%)$ who thought that this statement really describes them and somewhat like them, respectively. In this case, it implied that all of them had been actively using this strategy to understand what they hear. Besides, this strategy focuses on the individual's lexical knowledge to make meaning from the words they know. Furthermore, the strategy "I listen for what seems interesting" with the second highest mean score (2.60) reinforced the "I listen for the important words" strategy. This is because their active engagement of lexical knowledge was driven by their inquisitive approach to understand things that are interesting to them (Sabitovich, 2021). Therefore, the respondents were able to form meanings based on the important words and their willingness to learn something of interest to them in order to understand what they hear. In Section 3, the listening strategies are crucial information that the teachers should be attentive to when teaching listening skills to the language learners in the classroom, so the pupils are able to comprehend the language and content conveyed during the teaching and learning process. Chitravelu, Sithamparam and Choon (2005) stated that learners would be unable to participate in the learning process if they could not comprehend what the teacher is saying in the classroom. It is further elaborated that the objective of teaching listening skill is to develop pupils' ability to listen with understanding and obtain precise information.

Section 4 in the questionnaire was to further excavate the depth of the respondents' listening strategies if they still do not understand what someone says. Table 2 (Section 4) revealed that 39 respondents (97.5\%) used the "I guess the meaning from the person's tone (such as angry or happy)" strategy with the highest mean score (2.63) if they still do not understand what someone says. In addition, only 1 (2.5\%) out of 40 respondents did not use the strategy. It implied that most of the respondents were perceptive in receiving input and made meaning based on someone's tone to process whether the information conveyed were negative or positive. It helped them to better understand what someone says if they still do not understand after using the strategies from Section 3. This signified that the respondents attached certain tones (such as angry or happy) to words. Hence, the input they get from the tone helps them to guess the meaning of what someone says. Aside from that, the strategy "I guess the meaning from what I heard before" denoted the second highest mean score (2.33). Therefore, it indicated that the respondents also used their previous knowledge to guess the meaning when they still do not understand what someone says. Hence, they relied on the input they have from their prior knowledge to relate what they heard before and manipulate it to suit the current input that they cannot understand (Celik, 2020). The lowest mean score (1.63) was denoted by the strategy "I ask the person to slow down". This was 
probably because the suprasegmental feature of the language became unnatural. Thus, it would be harder for the respondents to understand unless they were only trying to understand certain words from what someone says. It was relevant to what Chitravelu, Sithamparam and Choon (2005) stressed that learners would not be able to understand if the speaker slowed down their speed of speech. Despite that, except for the strategy, "I ask the person to slow down", the other strategies have a high mean score of 2.00 and above. Hence, there were various strategies that the respondents used if they still do not understand what someone says in order to comprehend the speakers.

Table 2: Distribution, frequency and mean on listening strategies use

\begin{tabular}{|c|c|c|c|c|c|}
\hline No. & Item & $\begin{array}{c}\text { The } \\
\text { statement } \\
\text { isn't like } \\
\text { you } \\
(\%)\end{array}$ & $\begin{array}{l}\text { The } \\
\text { statement is } \\
\text { somewhat } \\
\text { like you (\%) }\end{array}$ & $\begin{array}{c}\text { The } \\
\text { statement } \\
\text { really } \\
\text { describes } \\
\text { you (\%) }\end{array}$ & Mean \\
\hline \multicolumn{6}{|c|}{ Section 1: What I do to listen more } \\
\hline 1 & $\begin{array}{l}\text { I listen to the songs in English } \\
\text { (YouTube videos/radio). }\end{array}$ & $2(5.0)$ & $25(62.5)$ & $13(32.5)$ & 2.28 \\
\hline 2 & I watch TV shows in English. & $5(12.5)$ & $26(65.0)$ & $9(22.5)$ & 2.10 \\
\hline 3 & $\begin{array}{l}\text { I go to movies that use the } \\
\text { language. }\end{array}$ & $3(7.5)$ & $18(45.0)$ & $19(47.5)$ & 2.40 \\
\hline 4 & $\begin{array}{l}\text { I listen to English if I am in a } \\
\text { restaurant or see movies in the } \\
\text { language. }\end{array}$ & 0 & $19(47.5)$ & $21(52.5)$ & 2.53 \\
\hline 5 & $\begin{array}{l}\text { If I hear people speaking English, I } \\
\text { listen. }\end{array}$ & $1(2.5)$ & $11(27.5)$ & $28(70.0)$ & 2.68 \\
\hline \multicolumn{6}{|c|}{ Section 2: What I do to understand sound } \\
\hline 6 & $\begin{array}{l}\text { I find sounds in the language that } \\
\text { are like sounds in English. }\end{array}$ & $8(20.0)$ & $28(70.0)$ & $4(10.0)$ & 1.90 \\
\hline 7 & $\begin{array}{l}\text { I try to remember unfamiliar } \\
\text { sounds I hear in English. }\end{array}$ & $3(7.5)$ & $24(60.0)$ & $13(32.5)$ & 2.25 \\
\hline 8 & $\begin{array}{l}\text { I listen to the rise and fall of } \\
\text { sounds (the tones in English). }\end{array}$ & $4(10.0)$ & $10(25.0)$ & $26(65.5)$ & 2.55 \\
\hline 9 & $\begin{array}{l}\text { I listen to the rise and fall of the } \\
\text { sounds (the music of the } \\
\text { language). }\end{array}$ & $6(15.0)$ & $17(42.5)$ & $17(42.5)$ & 1.85 \\
\hline
\end{tabular}




\section{Section 3: What I do to understand what I hear}

\begin{tabular}{|c|c|c|c|c|c|}
\hline 10 & I listen for the important words. & 0 & $11(27.5)$ & $29(72.5)$ & 2.73 \\
\hline 11 & $\begin{array}{l}\text { I listen for what seems } \\
\text { interesting. }\end{array}$ & $2(5.0)$ & $12(30.0)$ & $26(65.0)$ & 2.60 \\
\hline 12 & $\begin{array}{l}\text { I listen for words that are } \\
\text { repeated. }\end{array}$ & $2(5.0)$ & $27(67.5)$ & $11(27.5)$ & 2.23 \\
\hline \multicolumn{6}{|c|}{ Section 4: What I do if I still don't understand what someone says } \\
\hline 13 & I ask the person to repeat. & $7(17.5)$ & $26(65.0)$ & $7(17.5)$ & 2.00 \\
\hline 14 & I ask the person to slow down. & $17(42.5)$ & $21(52.5)$ & $2(5.0)$ & 1.63 \\
\hline 15 & I ask a question. & $4(10.0)$ & 31 (77.5) & 5 (12.5) & 2.03 \\
\hline 16 & $\begin{array}{l}\text { I guess the meaning from the } \\
\text { person's tone (such as angry or } \\
\text { happy). }\end{array}$ & $1(2.5)$ & $13(32.5)$ & $26(65.0)$ & 2.63 \\
\hline 17 & $\begin{array}{l}\text { I guess the meaning from how the } \\
\text { person moves or stands. }\end{array}$ & $7(17.5)$ & $19(47.5)$ & $14(35.0)$ & 2.18 \\
\hline 18 & $\begin{array}{l}\text { I guess the meaning from what I } \\
\text { heard before. }\end{array}$ & $3(7.5)$ & $21(52.5)$ & $16(40.0)$ & 2.33 \\
\hline
\end{tabular}

\section{Research Question 2}

To what extent do the Primary 6 ESL learners use speaking strategies in their language learning process?

The information tabulated in Table 3 focused on speaking strategies used by the respondents. As shown in Section 1 of the table, the strategies were used to practise speaking by the respondents. The strategy "I make the sounds of the language until I can say them well" denoted the highest mean score (2.25) with 36 respondents $(90 \%)$ that used the strategy to practise speaking. The sound of the English language is made up of phonemes. The respondents' first language, which is Chinese language, is a tonal language that essentially emphasised the tones and sounds to differentiate the homophonic character and its meanings. Therefore, the respondents were more familiar with practising the sounds of the language in order to speak the language. Khan, M. and Khan, R. (2021) noted that having an awareness of the sounds of the target language will improve the learner's ability to acquire the language.

Next, the strategy with the second highest mean score $(2.15)$ is the "I practise using new grammar forms when I talk". Therefore, the respondents were aware of the grammatical rules in the target language and actively implemented their knowledge into their speaking practice. As stated by Celce-Murcia and Larsen-Freeman (1999) that the ability to use language grammatically and communicate are respectively different from each other, but both are equally important goals. Thus, it implied that the respondents were practising their fluency in 
the language and applying their skill to use the language in terms of grammar accurately. The other two strategies, "I imitate the way native speakers talk" and "I say new expressions over to myself", respectively have mean scores of 1.90 and 1.98 . This is presumably due to their lack of exposure to the language, especially to native speakers and social factors. The respondents live in Malaysia, so they were more likely exposed to localised English expressions and accents. Hence, they are least likely to use these strategies to practise their speaking.

Subsequently, the next section in Table 3, which is Section 2, focused on the strategies used by the respondents in order to talk to others. There were 39 respondents $(97.5 \%)$ that used "I plan what I am going to say" strategy with the highest mean score (2.48), and only 1 respondent did not use the strategy to practise speaking. It is in line with their strategy to practice speaking, whereby the respondents practised using new grammar forms when they talk. This implied that the respondents were conscious of their grammar usage when they are talking. Therefore, their speech formation is more organised and more likely to be grammatically accurate. Hence, the conveyed information is comprehensible to a certain extent. However, the "I ask the other person to correct me when I talk" strategy denoted the lowest mean score (1.75) with 16 respondents (40\%) that did not use this strategy to talk to others. This might be because they prefer their speech flow to be uninterrupted. Roberts (1995) explained the necessity of error correction in language learning and suggested to allow the conversation flow.

The findings based on Table 3 (Section 3) revealed that 40 respondents (100\%) preferred to use the "I try to say it in a different way" strategy with the highest mean score of 2.53 . It is common to experience that moment when people are unable to think of the word or phrase that they want to say. Therefore, the respondents opted to elaborate on the things they wanted to say differently instead of trying to remember the certain words or phrases they wanted to say. It is to avoid interruption to the flow of conversation and their train of thoughts. Next, there were two strategies with the second highest mean score of 2.48, which are "I ask the person to help" and "I use words from my own language". The "I ask the person to help" strategy only has one respondent that did not use it. This indicated that most of the respondents were not afraid or embarrassed to request help from other people. Meanwhile, the other strategy indicated that the respondents rather use words from their own language to let the conversation flow when they could not think of the word or phrase to say. Castro and Artiles (2021) illuminated the parts where bilingualism influenced speaking competency. Hence, the respondents could not think of the word or phrase to say because of their mother tongue interference. The lowest mean score (1.93) is denoted by the "I move my hands or body so the person will understand me" strategy. It was probably because the respondents were not adept in using their bodily gestures to express themselves when they are talking, or they are not kinaesthetic types of learners. 
Table 3: Distribution, frequency and mean on speaking strategies use

\begin{tabular}{|c|c|c|c|c|c|}
\hline No. & Item & $\begin{array}{c}\text { The } \\
\text { statement } \\
\text { isn't like } \\
\text { you } \\
\text { (\%) }\end{array}$ & $\begin{array}{l}\text { The } \\
\text { statement is } \\
\text { somewhat } \\
\text { like you (\%) }\end{array}$ & $\begin{array}{c}\text { The } \\
\text { statement } \\
\text { really } \\
\text { describes } \\
\text { you }(\%)\end{array}$ & Mean \\
\hline \multicolumn{6}{|c|}{ Section 1: What I do to practice speaking } \\
\hline 1 & $\begin{array}{l}\text { I make the sounds of the language } \\
\text { until I can say them well. }\end{array}$ & $4(10.0)$ & $22(55.0)$ & $14(35.0)$ & 2.25 \\
\hline 2 & $\begin{array}{l}\text { I imitate the way native speakers } \\
\text { talk. }\end{array}$ & $7(17.5)$ & $27(67.5)$ & $5(12.5)$ & 1.90 \\
\hline 3 & $\begin{array}{l}\text { I say new expressions over to } \\
\text { myself. }\end{array}$ & $9(22.5)$ & $23(57.5)$ & $8(20.0)$ & 1.98 \\
\hline 4 & $\begin{array}{l}\text { I practise using new grammar } \\
\text { forms when I talk. }\end{array}$ & $6(15.0)$ & $22(55.0)$ & $12(30.0)$ & 2.15 \\
\hline \multicolumn{6}{|c|}{ Section 2: What I do to talk with other people } \\
\hline 6 & I start conversations. & $3(7.5)$ & $27(67.5)$ & $10(25.0)$ & 2.18 \\
\hline 7 & $\begin{array}{l}\text { I change the subject if I don't have } \\
\text { the words I need. }\end{array}$ & $6(15.0)$ & $15(37.5)$ & $19(47.5)$ & 2.33 \\
\hline 8 & I plan what I am going to say. & $1(2.5)$ & $19(47.5)$ & $20(50.0)$ & 2.48 \\
\hline 9 & $\begin{array}{l}\text { I ask the other person to correct } \\
\text { me when I talk. }\end{array}$ & $16(40.0)$ & $18(45.0)$ & $6(15.0)$ & 1.75 \\
\hline \multicolumn{6}{|c|}{ Section 3: What I do if I can't think of a word or phrase I want to say } \\
\hline 10 & I ask the person to help. & $1(2.5)$ & $19(47.5)$ & $20(50.0)$ & 2.48 \\
\hline 11 & I try to say it in a different way. & 0 & $19(47.5)$ & $21(52.5)$ & 2.53 \\
\hline 12 & $\begin{array}{l}\text { I use words from my own } \\
\text { language. }\end{array}$ & $3(7.5)$ & $15(37.5)$ & $22(55.0)$ & 2.48 \\
\hline 13 & $\begin{array}{l}\text { I use words from my own } \\
\text { language but say them with } \\
\text { sounds from the new language. }\end{array}$ & $5(12.5)$ & $20(50.0)$ & $15(37.5)$ & 2.25 \\
\hline 14 & $\begin{array}{l}\text { I move my hands or body so the } \\
\text { person will understand me. }\end{array}$ & $11(27.5)$ & $21(52.5)$ & $8(20.0)$ & 1.93 \\
\hline
\end{tabular}




\section{Implications and Conclusion}

The findings of this study give a reflection on how pupils learn English, especially in listening and speaking skills. Based on the findings, it can be said that demographic and learners' first language somehow affect learners' learning strategies. Learners with more exposure to the targeted language seemed to use the strategies of listening and practising to use the language in their daily life. Thus, it is important for learners to know their suitable learning strategies for them to enhance their skills in the English language. It also acts as an input for pupils to be aware of their learning strategies that can be used to improve their speaking and listening skills. However, it is important to bear in mind that teachers play a crucial role in introducing good language learning strategies to pupils. Research has shown that proficiency is related to language learning strategies. However, not all pupils preferred the same language learning strategies. It differs from one learner to another as they use certain types of language learning strategies that are suitable for themselves. Thus, teachers should identify the pupils' learning styles and preferences. Then, teachers should act as the facilitator in guiding them to various types of language learning strategies so that learners can try and choose strategies that suit their styles and preferences. Pupils should also be given the autonomy to choose strategies that suit their preferences in enhancing their English learning. Although this study documented the language learning strategies of Year 6 pupils focusing on listening and speaking skills, it did not cover the language learning skills of reading, writing and grammar as well as the factors influencing the choice of language learning strategies by the pupils. Future research can focus on the factors influencing the use of the language learning skills and or studies involving other skills, apart from listening and speaking, among primary school pupils in Malaysia and provide additional insights into L2 learning strategies that can help primary school students and teachers in applying the strategies in their learning and teaching strategies.

Although there are several language learning strategies accessible to learners and teachers alike today, not all are appropriate for every learner, based on the findings of this study. Teachers must assist pupils in determining the most suitable listening and speaking language learning strategies for them in order to enhance their learning. This study also demonstrated that numerous ways can be used to teach and learn the English language to the learners of all levels of education and not only to primary school pupils. To summarise, this study provides a new insight on the topic of language learning methodologies, and it will undoubtedly be of tremendous benefit to instructors and pupils in the future, particularly in the teaching and learning of English.

\section{References}

Brown, H. D. (1994). Principles of Language Learning and Teaching. 3rd ed. Englewood Cliffs, NJ: Prentice Hall Regents.

Castro, D. C., \& Artiles, A. J. (Eds.). (2021). Language, Learning, and Disability in the Education of Young Bilingual Children. Multilingual Matters.

Celce-Murcia, M., Brinton, D. M., \& Snow, M. A. (2014). Teaching English as a Second or Foreign Language, 4th ed. USA: National Geographic Learning.

Celce-Murcia, M., \& Larsen-Freeman, D. (1999). The Grammar Book: An ESL/EFL Teacher's Course, 2nd ed. USA: Heinle Cengage Learning.

Celik, B. (2020). The use of scaffolding techniques in language learning: Extending the level of understanding. International Journal of Social Sciences \& Educational Studies, 7(3), 148. 
Chamot, A. U. (1999). Children's learning strategies in language immersion classrooms. The Modern Language Journal, 83(3), 319-339.

Chamot, A. (2005). Language Learning Strategy Instruction: Current Issues And Research. Annual Review of Applied Linguistics, 25, 112-130. doi:10.1017/S0267190505000061.

Chitravelu, N., Sithamparam, S., \& Choon, T. S. (2005). ELT Methodology: Principles and Practice, 2nd ed. Selangor: Oxford Fajar.

Cohen, A. D. (1990). Language learning. Boston: Heinle and Heinle.

Cohen, A. D. (1998). Strategies in Learning and Using a Second Language. Essex, U.K.: Longman.

Cohen, A. D., Oxford, R. L., \& Chi, J. C. (2002). Language strategy use survey. Minneapolis, MN: Center for Advanced Research on Language Acquisition, University of Minnesota.

Cohen, A. D., \& Chi, J. C. (2004). Language Strategy Use Inventory. In R. M. Paige, A. D. Cohen, B. Kapper, J. C. Chi, \& J. P. Lassegard (Eds.), Maximising study abroad: A students' guide to strategies for language and culture learning and use(pp. 16-22). Minneapolis, MN: Center for Advanced Research on Language Acquisition, University of Minnesota.

Ellis, R. (1994). The Study of Second Language Acquisition. Oxford: Oxford University Press.

Faerch, C. \& Kasper, G. (1984). Strategies in Interlanguage Communication. London: Longman.

Gharbavi, A., \& Mousavi, S. A. (2012). Do Language Proficiency Levels Correspond to Language Learning Strategy Adoption?. English Language Teaching, 5(7), 110-122.

Gilbert, J. (2005). Catching the knowledge wave? The knowledge society and the future of education. Wellington: NZCER Press.

Green, J., \& Oxford, R. L. (1995). A closer look at learning strategies, L2 proficiency and gender. TESOL Quarterly, 29(2): 261-297.

Gregersent, T. (2001). Can foreign language learning strategies turn into crutches? A pilot study on the use of strategies by successful and unsuccessful language learners. Revista Signos, 34, 49-50,

Griffiths, C. \& Parr, J. (2001). Language learning strategies: Theory and perception. ELT Journal, 55(3).

Habók, A., \& Magyar, A. (2018). The effect of language learning strategies on proficiency, attitudes and school achievement. Frontiers in psychology, 8, 2358.

Khan, M., \& Khan, R. (2021). Phonological Awareness and Phonics Instruction: Inclusive practice that benefits all kinds of learners. Asia Pacific Journal of Developmental Differences, 8(1), 173-185.

Kumaravadivelu, B. (2003). Beyond Methods: Macrostrategies for Language Teaching. New Haven: Yale University Press.

Lessard-Clouston, M. (1997). Language Learning Strategies: An Overview for L2 Teachers. Internet TESL Journal. http://iteslj.org/Articles/Lessard-Clouston-Strategy.

Macaro, E. (2014). Fourteen Features of a Language Learner Strategy. Working paper, 4.

Murat, H. (2000). Language learning strategies in foreign language learning and teaching. The Internet TESL Journal, 6(8).

Naiman, N., Frohlich, M., Stern, H., \& Todesco, A. (2018). The good language learner. Research in Education Series No.7. Toronto: The Ontario Institute for Studies in Education.

Nunan, D. (1997). Approaches to teaching listening in the language classroom. In Plenary (p. 1).

O'Malley, J. M., \& Chamot, A. U. (1990). Learning Strategies in Second Language Acquisition. Cambridge, U.K.: Cambridge University Press. 
Ortega-Llebaria, M., \& Wu, Z. (2020). Chinese-English Speakers' Perception of Pitch in Their Non-Tonal Language: Reinterpreting English as a Tonal-Like Language. Language and speech, 0023830919894606.

Oxford, R., \& Nyikos, M. (1989). Variables affecting choice of language learning strategies by university students. The Modern Language Journal, 3(3).

Purpura, J. (1999). Learner characteristics and L2 test performance. In R. L. Oxford (Ed.), Language Learning Strategies in the Context of Autonomy, Synthesis of Findings from the International Invitational Conference on Learning Strategy Research (pp. 61-63), Teachers College, Columbia University, New York, NY.

Raoofi, S., Binandeh, M., \& Rahmani, S. (2017). An investigation into writing strategies and writing proficiency of university students. Journal of Language Teaching and Research, 8(1), 191.

Richards, J., \& Platt, J. (1992). Longman Dictionary of Language Teaching and Applied Linguistics. Essex: Longman.

Roberts, M. (1995). Awareness and the efficacy of error correction. Attention and awareness in foreign language learning, 163-182.

Rubin, J. (1981). How to be a More Successful Language Learner. 2nd ed. Boston: Heinle and Heinle.

Rubin, J. (1994). How to be a More Successful Language Learner. 2nd ed. Boston: Heinle and Heinle.

Sabitovich, A. B. (2021). Listening skills of schoolchildren as an important factor of understanding and contemplation. The American Journal of Social Science and Education Innovations, 3(04), 588-594.

Sah, F., \& Shah, P. (2020) Teachers' Beliefs and Practices in Teaching Listening. Creative Education, 11, 182-195. doi: 10.4236/ce.2020.112013.

Shin, J. K., \& Crandall, J. (2014). Teaching Young Learners English: From Theory to Practice. USA: National Geographic Learning.

Suwanarak, K. (2019). Use of Learning Strategies and their Effects on English Language Learning of Thai Adult Learners. 3L: Language, Linguistics, Literature ${ }^{\circledR}, 25(4)$.

Ulum, Ö. G. (2015). Listening: The Ignored Skill in EFL Context. Online Submission, 2(5), 72-76.

Wenden, A. (1991). Learner strategies for learner autonomy: Planning and implementing learner training for language learners. New York: Prentice Hall.

Wolff, M., Wagner, M. J., Poznanski, S., Schiller, J., \& Santen, S. (2015). Not another boring lecture: engaging learners with active learning techniques. The Journal of emergency medicine, 48(1), 85-93.

Wong-Fillmore, L. (1979). Individual differences in second language acquisition. In C. Filmore, D. Kempler, \& W. Wang (Eds.), Individual differences in language ability and language behaviour (pp.203-228). New York: Academic Press. 
INTERNATIONAL JOURNAL OF ACADEMIC RESEARCH IN BUSINESS AND SOCIAL SCIENCES Vol. 11, No. 6, 2021, E-ISSN: 2222-6990 @ 2021 HRMARS

\section{Appendix - Questionnaire}

\section{Young Learners' Language Strategy Use Survey (Cohen \&}

\section{Oxford, 2002)}

This survey of Language Strategy Use is divided to two section (Listening and Speaking). Please read through the questions and answer accordingly. If the statement really describes you, put a score of (100\%) If the statement is somewhat like you, put a score of ( $50 \%)$. If the statement is not like you, put a score of $(0 \%)$

* Required

1. Name: *

2. Gender: *

Mark only one oval.
Male
Female

Click next to start the survey.

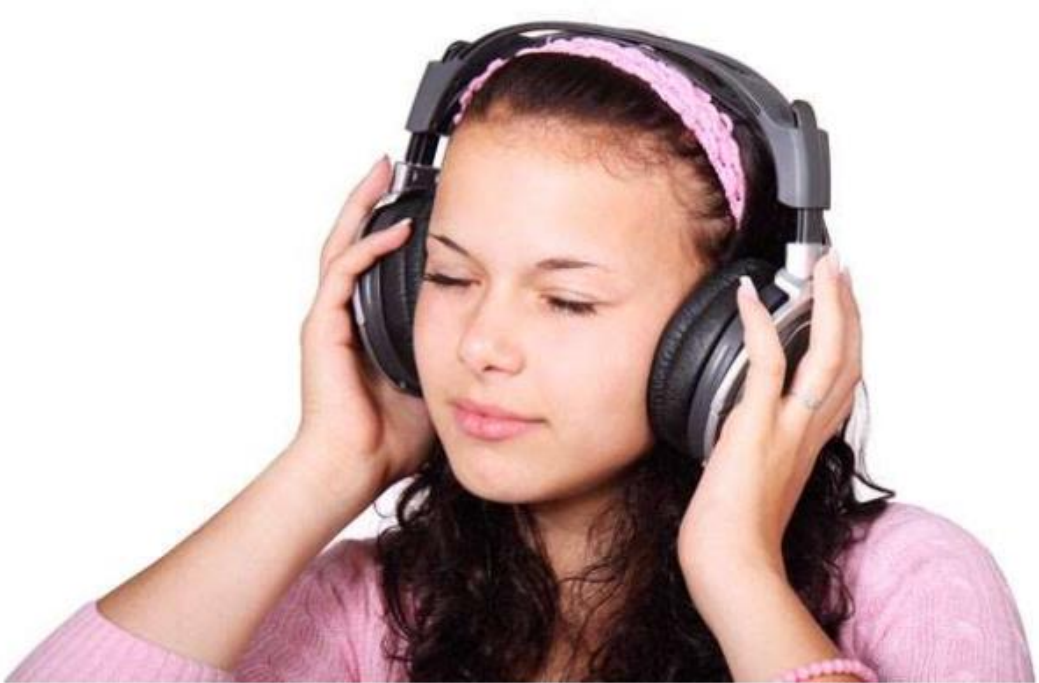

Listening Strategies 
INTERNATIONAL JOURNAL OF ACADEMIC RESEARCH IN BUSINESS AND SOCIAL SCIENCES Vol. 11, No. 6, 2021, E-ISSN: 2222-6990 @ 2021 HRMARS

3. Section 1: What I do to listen more: *

Check all that apply.

1. I listen to the songs in English (YouTube
videos / radio).
2. I watch TV shows in English.
3. I go to movies that use the language.
4. I listen to English if I am in a restaurant or
see movies in the language.
5. If I hear people speaking English, I listen.

4. Section 2: What I do to understand sounds: *

Check all that apply.

100\% $\quad 50 \% \quad 0 \%$
$\begin{aligned} & \text { 6. I find sounds in the language that are like } \\ & \text { sounds in English. }\end{aligned}$

7. I try to remember unfamiliar sounds I hear in English.

8. I listen to the rise and fall of sounds (the tones in English).

9. I listen to the rise and fall of the sounds (the music of the language).

5. Section 3: What I do to understand what I hear: *

Check all that apply.

\begin{tabular}{l|l}
\hline 10. I listen for the important words. \\
\hline 11. I listen for what seems interesting. \\
\hline 12. I listen for words that are repeated.
\end{tabular}


INTERNATIONAL JOURNAL OF ACADEMIC RESEARCH IN BUSINESS AND SOCIAL SCIENCES

Vol. 11, No. 6, 2021, E-ISSN: 2222-6990 @ 2021 HRMARS

6. Section 4: What I do if I still don't understand what someone says: *

Check all that apply.

13. I ask the person to repeat.
14. I ask the person to slow down.
15. I ask a question.

16. I guess the meaning from the person's

tone (such as angry or happy)

17. I guess the meaning from how the person moves or stands.

18. I guess the meaning from what I heard before.

Click next to answer questions about Speaking Strategies.

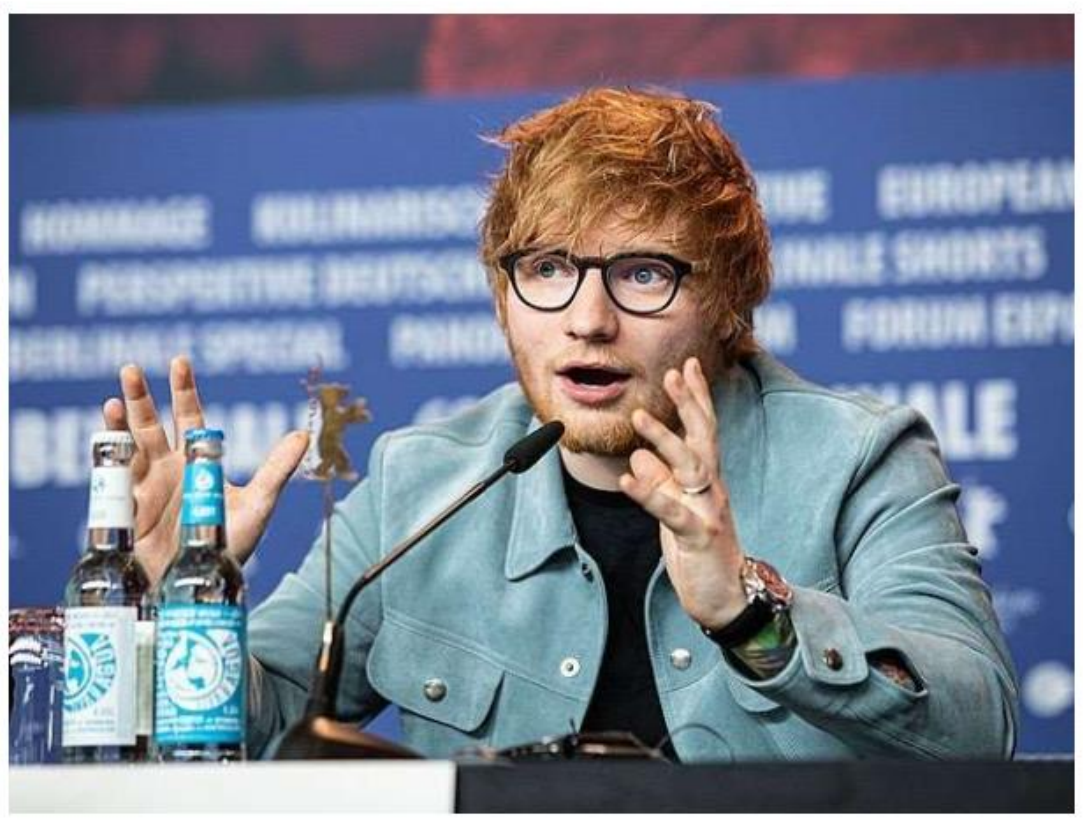

Speaking Strategies 
INTERNATIONAL JOURNAL OF ACADEMIC RESEARCH IN BUSINESS AND SOCIAL SCIENCES Vol. 11, No. 6, 2021, E-ISSN: 2222-6990 @ 2021 HRMARS

7. Section 1: What I do to practise speaking?

Check all that apply.

19. I make the sounds of the language until I
can say them well.
20. I imitate the way native speakers talk.
21. I say new expressions over to myself.
22. I practise using new grammar forms
when I talk.

8. Section 2: What I do to talk with other people:

Check all that apply.

23. I start conversations.
$\begin{aligned} & \text { 24. I change the subject if I don't have the } \\ & \text { words I need. }\end{aligned}$

25. I plan what I am going to say.

26. I ask the other person to correct me when I talk.

9. Section 3: What I can't think of a word or phrase I want to say: *

Check all that apply.

\begin{tabular}{llll} 
& $100 \%$ & $50 \%$ & $0 \%$ \\
\hline 27. I ask the person to help. & $\square$ & $\square$ & $\square$ \\
\hline
\end{tabular}

28. I try to say it a different way.

29. I use words from my own language.

30. I use words from my own language but say them with sounds from the new

language.

31. I move my hands or body so the person will understand me. 
INTERNATIONAL JOURNAL OF ACADEMIC RESEARCH IN BUSINESS AND SOCIAL SCIENCES Vol. 11, No. 6, 2021, E-ISSN: 2222-6990 @ 2021 HRMARS

You have completed the survey. Thank you :)

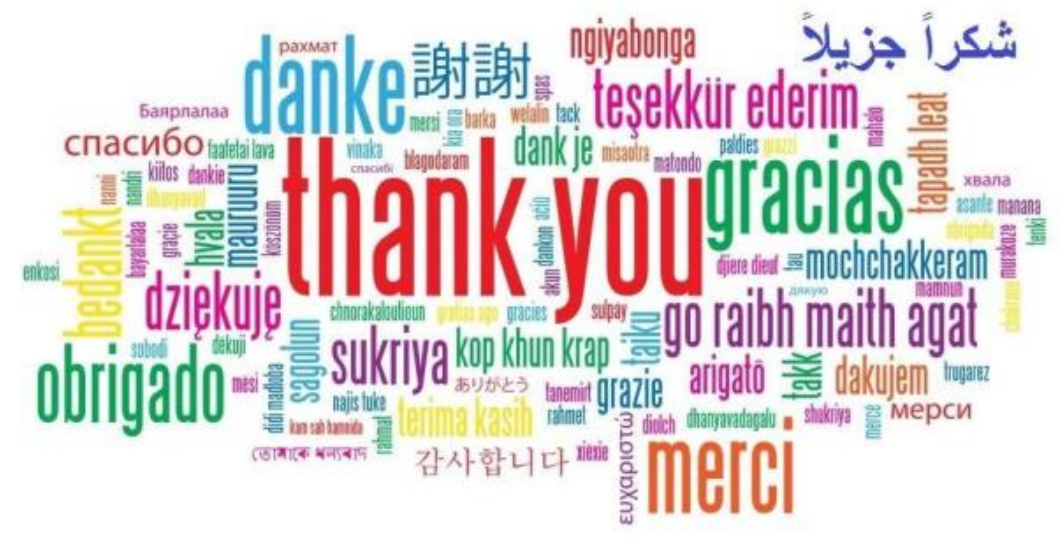

This content is neither created nor endorsed ty Google.

Google Forms 